\title{
44. PALEOMAGNETISM OF SEDIMENTS, LEG 34
}

\author{
James M. Ade-Hall and Harlan Paul Johnson, ${ }^{1}$ Department of Geology, \\ Dalhousie University, Halifax, Nova Scotia, Canada
}

\section{INTRODUCTION}

Stimulated by the paleomagnetic results from the basalts sampled at Site 319 , which could be interpreted in terms of large northward motion of the Nazca plate, a program of sediment paleomagnetism was initiated on Glomar Challenger during Leg 34. Additional measurements have been made at Dalhousie University. It was reasoned that one of the explanations for the Site 319 basalt paleomagnetic results, magnetization over a short time interval when the geomagnetic field deviated markedly from a centered axial dipole state, could be tested by determining the paleomagnetic inclinations of the sediments overlying and presumably only slightly younger than the basalts. Since the sedimentation rate during this interval was 2.8 to $4.2 \mathrm{~cm} / 10^{3} \mathrm{yr}$, a single 2.5 $\mathrm{cm}$ sediment sample should yield an average value of the paleomagnetic field for a 600-900 yr interval, and a series of samples should give a representative average value for several million years. Should the average sediment inclination lie closer to the anticipated value for the site latitude, major plate motion could be excluded as an explanation for the aberrant basalt result. The clear answer from this experiment encouraged sampling of the deeper sediments at Sites 320 and 321 and has led to a consideration of the important problems of the motion of the plate as a whole and of the source of the magnetization of the sediments.

\section{EXPERIMENTAL METHOD}

Approximately 6-cc samples were taken from the working half of sediment cores by using $1.9-\mathrm{cm}$ internal diameter plastic sleeves cut from plastic sample bottles. The location and sense of the vertical axis of the main core was transferred to the sample by pressing the sleeve into the sediment so that the marked diameter of the sleeve lay along a line parallel to the axis of the main core. The natural remanent magnetization (NRM) of the sediments was measured and partly demagnetized using the shipboard paleomagnetic facility (see AdeHall and Johnson, Paleomagnetism of Basalts, this volume). The shipboard demagnetizing unit induced anhysteritic remanent magnetization in many samples at fields of 100 or 150 oe, thereby obscuring the important remanent information for some samples. However, demagnetization to higher fields at Dalhousie University using a Schonstedt GSD-1 unit allowed recovery of this information in most instances. Of 36 samples taken, 32 gave apparently reliable measurements of the paleomagnetic field inclination.

'Now at CIRES, P.S.R.B. No. 1, University of Colorado, Boulder, 'Now at
Colorado.

\section{RESULTS}

\section{Cleaned NRM Inclinations}

Table 1 lists the paleomagnetic directions for the samples. In most cases the removal of a soft component of magnetization during initial demagnetization is evi-

TABLE 1

Paleomagnetic Directions for Sediment Samples

$\left.\begin{array}{crlll}\hline & \text { Sample } & & & \\ \text { Sample (Depth } & \begin{array}{c}\text { Demagneti- } \\ \text { zation }\end{array} & & & \\ \text { Below Mudline, m) } & \text { Field } & J^{\mathrm{b}} & \phi^{\mathrm{c}} & I^{\mathrm{d}} \\ \hline 319-1-6,11.5 \mathrm{~cm} & 0 & 4.6 & 303 & +54 \\ (7.615) & 50 & 4.7 & 309 & +72 \\ & 100 & 5.5 & 276 & +55 \\ & 150 & 2.8 & 262 & +41 \\ 319-3-3,25 \mathrm{~cm}^{\mathrm{e}} & 0 & 2.8 & 102 & +48 \\ (22.25) & 50 & 1.6 & 097 & +49 \\ & 100 & 1.4 & 090 & +55 \\ & 150 & 1.2 & 0.91 & +59 \\ & 200 & 0.90 & 091 & +50 \\ & 250 & 0.69 & 097 & +54 \\ & 300 & 0.50 & 094 & +55\end{array}\right\}+55^{(8)}$


TABLE 1 - Continued

\begin{tabular}{|c|c|c|c|c|c|}
\hline $\begin{array}{c}\text { Sample (Depth } \\
\text { Below Mudline, m) }\end{array}$ & $\begin{array}{c}\text { Samplea } \\
\text { Demagneti- } \\
\text { zation } \\
\text { Field }\end{array}$ & $J^{\mathrm{b}}$ & $\phi^{\mathrm{c}}$ & $I^{\mathrm{d}}$ & \\
\hline $\begin{array}{c}319-12-3,132.5 \mathrm{~cm}^{\mathrm{f}} \\
(108.825)\end{array}$ & $\begin{array}{r}0 \\
50 \\
100 \\
150 \\
200\end{array}$ & $\begin{array}{l}3.3 \\
1.7 \\
1.6 \\
1.4 \\
1.2\end{array}$ & $\begin{array}{l}307 \\
304 \\
302 \\
299 \\
300\end{array}$ & $\left.\begin{array}{l}-09 \\
-05 \\
-03 \\
-05 \\
-06\end{array}\right\}$ & -05 \\
\hline $\begin{array}{c}320-2-2,60.5 \mathrm{~cm}^{\mathrm{e}} \\
(75.605)\end{array}$ & $\begin{array}{r}0 \\
50 \\
100 \\
150 \\
200\end{array}$ & $\begin{array}{l}4.4 \\
1.3 \\
1.2 \\
0.70 \\
0.59\end{array}$ & $\begin{array}{l}335 \\
348 \\
029 \\
256 \\
317\end{array}$ & $\begin{array}{l}+06 \\
+14 \\
+51 \\
+25 \\
+43\end{array}$ & \\
\hline $\begin{array}{c}320-3-6,111 \mathrm{~cm} \\
(110.59)\end{array}$ & $\begin{array}{r}0 \\
50 \\
100 \\
150 \\
250 \\
300\end{array}$ & $\begin{array}{l}1.3 \\
0.47 \\
0.39 \\
0.31 \\
0.16 \\
0.26\end{array}$ & $\begin{array}{l}076 \\
091 \\
106 \\
083 \\
224 \\
247\end{array}$ & $\begin{array}{l}-05 \\
+08 \\
-36 \\
-44 \\
-60 \\
-49\end{array}$ & \\
\hline $\begin{array}{c}320 \mathrm{~B}-1-1,6.5 \mathrm{~cm} \\
(136.65)\end{array}$ & $\begin{array}{r}0 \\
50 \\
100 \\
150 \\
200\end{array}$ & $\begin{array}{l}0.62 \\
0.46 \\
0.38 \\
0.40 \\
0.25\end{array}$ & $\begin{array}{l}023 \\
037 \\
041 \\
054 \\
036\end{array}$ & $\left.\begin{array}{l}-11 \\
-22 \\
-38 \\
-49 \\
-40\end{array}\right\}$ & -42 \\
\hline $\begin{array}{c}320 \mathrm{~B}-1-2,111.5 \mathrm{~cm}^{\mathrm{e}} \\
(138.65)\end{array}$ & $\begin{array}{r}0 \\
50 \\
100 \\
150 \\
200\end{array}$ & $\begin{array}{l}3.9 \\
2.7 \\
2.7 \\
2.4 \\
2.0\end{array}$ & $\begin{array}{l}045 \\
021 \\
016 \\
013 \\
012\end{array}$ & $\left.\begin{array}{l}-34 \\
-23 \\
-19 \\
-19 \\
-19\end{array}\right\}$ & -19 \\
\hline $\begin{array}{c}320 \mathrm{~B}-1-3,55 \mathrm{~cm}^{\mathrm{e}} \\
(139.55)\end{array}$ & $\begin{array}{r}0 \\
50 \\
100 \\
150 \\
200\end{array}$ & $\begin{array}{l}1.3 \\
0.97 \\
0.88 \\
0.90 \\
0.56\end{array}$ & $\begin{array}{l}304 \\
314 \\
313 \\
302 \\
311\end{array}$ & $\left.\begin{array}{l}00 \\
-03 \\
+06 \\
+03 \\
+05\end{array}\right\}$ & +05 \\
\hline $\begin{array}{c}320 \mathrm{~B}-1-4,101 \mathrm{~cm} \\
(141.51)\end{array}$ & $\begin{array}{r}0 \\
50 \\
100 \\
150 \\
200\end{array}$ & $\begin{array}{l}1.1 \\
1.0 \\
0.64 \\
0.68 \\
0.58\end{array}$ & $\begin{array}{l}241 \\
215 \\
199 \\
183 \\
190\end{array}$ & $\left.\begin{array}{l}+08 \\
+13 \\
+27 \\
+30 \\
+17\end{array}\right\}$ & +24 \\
\hline $\begin{array}{c}320 \mathrm{~B}-1-5,38 \mathrm{~cm} \\
(142.38)\end{array}$ & $\begin{array}{r}0 \\
50 \\
100 \\
150 \\
200\end{array}$ & $\begin{array}{l}1.5 \\
1.3 \\
1.2 \\
1.2 \\
1.0\end{array}$ & $\begin{array}{l}053 \\
055 \\
054 \\
059 \\
063\end{array}$ & $\left.\begin{array}{l}-04 \\
-06 \\
+01 \\
-05 \\
-03\end{array}\right\}$ & -04 \\
\hline $\begin{array}{c}320 \mathrm{~B}-1-6,37 \mathrm{~cm}^{\mathrm{g}} \\
(143.87)\end{array}$ & $\begin{array}{r}0 \\
50 \\
100 \\
150 \\
200\end{array}$ & $\begin{array}{l}0.79 \\
0.48 \\
0.45 \\
0.44 \\
0.51\end{array}$ & $\begin{array}{l}088 \\
073 \\
051 \\
065 \\
027\end{array}$ & $\begin{array}{l}+03 \\
+01 \\
-00 \\
-30 \\
-12\end{array}$ & \\
\hline $\begin{array}{c}320 \mathrm{~B}-1-6,106 \mathrm{~cm}^{\mathrm{g}} \\
(144.56)\end{array}$ & $\begin{array}{r}0 \\
50 \\
100 \\
150 \\
200\end{array}$ & $\begin{array}{l}0.96 \\
1.05 \\
0.95 \\
0.80 \\
0.72\end{array}$ & $\begin{array}{l}025 \\
022 \\
020 \\
015 \\
022\end{array}$ & $\left.\begin{array}{l}-07 \\
+06 \\
+14 \\
+26 \\
+09\end{array}\right\}$ & +16 \\
\hline $320 \mathrm{~B}-2-1,124 \mathrm{~cm}^{\mathrm{e}}$ & $\begin{array}{r}0 \\
50 \\
100 \\
150 \\
200\end{array}$ & $\begin{array}{l}0.52 \\
0.51 \\
0.49 \\
0.49 \\
0.41\end{array}$ & $\begin{array}{l}200 \\
176 \\
130 \\
158 \\
163\end{array}$ & $\left.\begin{array}{l}-63 \\
-58 \\
-46 \\
-60 \\
-61\end{array}\right\}$ & -61 \\
\hline $\begin{array}{c}320 \mathrm{~B}-2-2,50 \mathrm{~cm} \\
(147.50)\end{array}$ & $\begin{array}{r}0 \\
50 \\
100 \\
150 \\
200\end{array}$ & $\begin{array}{l}1.4 \\
0.97 \\
0.72 \\
0.75 \\
0.72\end{array}$ & $\begin{array}{l}068 \\
067 \\
054 \\
044 \\
041\end{array}$ & $\left.\begin{array}{l}-36 \\
-45 \\
-59 \\
-63 \\
-61\end{array}\right\}$ & -61 \\
\hline
\end{tabular}

TABLE 1 - Continued

\begin{tabular}{|c|c|c|c|c|c|}
\hline $\begin{array}{c}\text { Sample (Depth } \\
\text { Below Mudline, } \mathrm{m} \text { ) }\end{array}$ & $\begin{array}{l}\text { Sample }^{\mathrm{a}} \\
\text { Demagneti- }^{-} \\
\text {zation } \\
\text { Field }\end{array}$ & $J^{\mathrm{b}}$ & $\phi^{c}$ & $I^{\mathrm{d}}$ & \\
\hline $\begin{array}{c}320 \mathrm{~B}-2-3,121.5 \mathrm{~cm}^{\mathrm{e}} \\
(149.715)\end{array}$ & $\begin{array}{r}0 \\
50 \\
100 \\
150 \\
200\end{array}$ & $\begin{array}{l}2.4 \\
1.3 \\
1.1 \\
0.95 \\
0.72\end{array}$ & $\begin{array}{l}337 \\
354 \\
002 \\
000 \\
000\end{array}$ & $\left.\begin{array}{l}+03 \\
-11 \\
-15 \\
-11 \\
-11\end{array}\right\}$ & -12 \\
\hline $\begin{array}{c}320 \mathrm{~B}-2-5,42.5 \mathrm{~cm} \\
(151.925)\end{array}$ & $\begin{array}{r}0 \\
50 \\
100 \\
150 \\
200 \\
250\end{array}$ & $\begin{array}{l}0.99 \\
0.73 \\
0.59 \\
0.40 \\
0.39 \\
0.36\end{array}$ & $\begin{array}{l}340 \\
322 \\
310 \\
336 \\
309 \\
308\end{array}$ & $\left.\begin{array}{l}+18 \\
+26 \\
+33 \\
-24 \\
+16 \\
+31\end{array}\right\}$ & +24 \\
\hline $\begin{array}{c}320 \mathrm{~B}-2-5,107 \mathrm{~cm} \\
(156.57)\end{array}$ & $\begin{array}{r}0 \\
50 \\
100 \\
150 \\
200\end{array}$ & $\begin{array}{l}2.3 \\
1.5 \\
0.90 \\
0.81 \\
0.62\end{array}$ & $\begin{array}{l}008 \\
014 \\
010 \\
011 \\
013\end{array}$ & $\left.\begin{array}{l}-33 \\
-31 \\
-39 \\
-29 \\
-24\end{array}\right\}$ & -31 \\
\hline $\begin{array}{c}321-7-6,135 \mathrm{~cm} \\
(56.35)\end{array}$ & $\begin{array}{r}0 \\
50 \\
100 \\
150 \\
200\end{array}$ & $\begin{array}{r}12.2 \\
7.0 \\
5.1 \\
5.4 \\
3.7\end{array}$ & $\begin{array}{l}311 \\
318 \\
328 \\
305 \\
322\end{array}$ & $\left.\begin{array}{l}+09 \\
+15 \\
+14 \\
+18 \\
+20\end{array}\right\}$ & +19 \\
\hline $\begin{array}{c}321-9-2,119-120 \mathrm{~cm} \\
(70.69)\end{array}$ & $\begin{array}{r}0 \\
50 \\
100 \\
150 \\
200\end{array}$ & $\begin{array}{l}7.5 \\
4.6 \\
4.6 \\
4.1 \\
3.4\end{array}$ & $\begin{array}{l}045 \\
049 \\
049 \\
049 \\
048\end{array}$ & $\left.\begin{array}{r}+05 \\
+05 \\
+03 \\
+04 \\
+05\end{array}\right\}$ & $\begin{array}{l} \\
+04\end{array}$ \\
\hline $\begin{array}{c}321-9-6,39 \mathrm{~cm} \\
(75.89)\end{array}$ & $\begin{array}{r}0 \\
50 \\
100 \\
150 \\
200\end{array}$ & $\begin{array}{r}21.3 \\
11.1 \\
12.0 \\
11.2 \\
9.4\end{array}$ & $\begin{array}{l}056 \\
052 \\
054 \\
052 \\
051\end{array}$ & $\left.\begin{array}{l}+06 \\
+09 \\
+15 \\
+13 \\
+13\end{array}\right\}$ & +14 \\
\hline $\begin{array}{c}321-10-1,110 \mathrm{~cm} \\
(80.10)\end{array}$ & $\begin{array}{r}0 \\
50 \\
100 \\
150 \\
200\end{array}$ & $\begin{array}{l}4.2 \\
2.9 \\
2.6 \\
2.4 \\
2.3\end{array}$ & $\begin{array}{l}310 \\
318 \\
326 \\
327 \\
327\end{array}$ & $\left.\begin{array}{l}-02 \\
+03 \\
+14 \\
+04 \\
+05\end{array}\right\}$ & +05 \\
\hline $\begin{array}{c}321-10-3,86 \mathrm{~cm} \\
(81.36)\end{array}$ & $\begin{array}{r}0 \\
50 \\
100 \\
150 \\
200\end{array}$ & $\begin{array}{l}3.0 \\
1.8 \\
1.7 \\
1.5 \\
1.2\end{array}$ & $\begin{array}{l}054 \\
054 \\
045 \\
048 \\
044\end{array}$ & $\left.\begin{array}{l}-04 \\
-02 \\
-01 \\
+03 \\
+03\end{array}\right\}$ & +03 \\
\hline $\begin{array}{c}321-11-1,102 \mathrm{~cm} \\
(88.02)\end{array}$ & $\begin{array}{r}0 \\
50 \\
100 \\
150 \\
200\end{array}$ & $\begin{array}{l}4.5 \\
3.0 \\
2.4 \\
2.3 \\
2.0\end{array}$ & $\begin{array}{l}060 \\
062 \\
050 \\
051 \\
049\end{array}$ & $\left.\begin{array}{l}+06 \\
+06 \\
+06 \\
+07 \\
+07\end{array}\right\}$ & +07 \\
\hline $\begin{array}{c}321-11-2,55 \mathrm{~cm} \\
(89.05)\end{array}$ & $\begin{array}{r}0 \\
50 \\
100 \\
150 \\
200\end{array}$ & $\begin{array}{l}8.7 \\
4.9 \\
4.0 \\
3.5 \\
2.8\end{array}$ & $\begin{array}{l}314 \\
317 \\
321 \\
324 \\
323\end{array}$ & $\left.\begin{array}{l}+11 \\
+16 \\
+16 \\
+19 \\
+19\end{array}\right\}$ & +18 \\
\hline $\begin{array}{c}321-11-3,18 \mathrm{~cm} \\
(90.18)\end{array}$ & $\begin{array}{r}0 \\
50 \\
100 \\
150 \\
200\end{array}$ & $\begin{array}{l}2.1 \\
1.7 \\
1.7 \\
1.6 \\
1.4\end{array}$ & $\begin{array}{l}353 \\
352 \\
348 \\
348 \\
337\end{array}$ & $\left.\begin{array}{l}+02 \\
+10 \\
+13 \\
+12 \\
+19\end{array}\right\}$ & +12 \\
\hline $\begin{array}{c}321-11-4,12 \mathrm{~cm} \\
(91.62)\end{array}$ & $\begin{array}{r}0 \\
50 \\
100 \\
150 \\
200\end{array}$ & $\begin{array}{l}3.9 \\
2.8 \\
2.5 \\
2.2 \\
1.8\end{array}$ & $\begin{array}{l}054 \\
0.51 \\
045 \\
053 \\
052\end{array}$ & $\left.\begin{array}{l}+05 \\
+05 \\
+11 \\
+09 \\
+06\end{array}\right\}$ & +09 \\
\hline
\end{tabular}


TABLE 1 - Continued

\begin{tabular}{|c|c|c|c|c|c|}
\hline $\begin{array}{c}\text { Sample (Depth } \\
\text { Below Mudline, m) }\end{array}$ & $\begin{array}{l}\text { Sample }^{\mathrm{a}} \\
\text { Demagneti- } \\
\text { zation } \\
\text { Field } \\
\end{array}$ & $J^{\mathrm{b}}$ & $\phi^{\mathrm{c}}$ & $I^{\mathrm{d}}$ & \\
\hline $\begin{array}{c}321-13-1,123 \mathrm{~cm} \\
(116.79)\end{array}$ & $\begin{array}{r}0 \\
50 \\
100 \\
150 \\
200\end{array}$ & $\begin{array}{l}5.8 \\
3.8 \\
5.6 \\
4.3 \\
3.2\end{array}$ & $\begin{array}{l}054 \\
083 \\
072 \\
074 \\
069\end{array}$ & $\left.\begin{array}{l}-08 \\
+01 \\
+35 \\
+28 \\
+22\end{array}\right\}$ & $\begin{array}{l} \\
+25\end{array}$ \\
\hline $\begin{array}{c}321-13-2,99 \mathrm{~cm} \\
(117.99)\end{array}$ & $\begin{array}{r}0 \\
50 \\
100 \\
150 \\
200\end{array}$ & $\begin{array}{l}1.9 \\
1.3 \\
1.9 \\
1.5 \\
1.2\end{array}$ & $\begin{array}{l}036 \\
002 \\
349 \\
352 \\
348\end{array}$ & $\left.\begin{array}{l}+04 \\
+33 \\
+32 \\
+37 \\
+37\end{array}\right\}$ & +37 \\
\hline $\begin{array}{c}321-13-3,85 \mathrm{~cm} \\
(119.35)\end{array}$ & $\begin{array}{r}0 \\
50 \\
100 \\
150 \\
200\end{array}$ & $\begin{array}{l}2.1 \\
1.1 \\
1.5 \\
0.92 \\
0.68\end{array}$ & $\begin{array}{l}018 \\
326 \\
325 \\
313 \\
339\end{array}$ & $\left.\begin{array}{l}-12 \\
-30 \\
-19 \\
-29 \\
-14\end{array}\right\}$ & -21 \\
\hline
\end{tabular}

${ }^{\mathrm{a}}$ Peak demagnetization field (oe).

$\mathrm{b}_{\text {Remanent magnetization intensity ( }} 10^{6} \mathrm{emu} \mathrm{cm}^{-3}$ ).

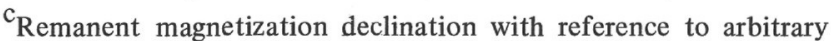
reference line marked on core $\left({ }^{\circ}\right)$.

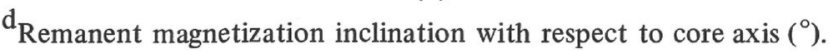

${ }^{\mathrm{e}}$ Sediment may have flowed in liner before sampling.

$\mathrm{f}_{\text {Indicates that successive samples have the same aximuthal }}$ orientation.

$\mathrm{g}_{\text {Indicates that successive samples have the same aximuthal }}$ orientation.

dent, as is the common addition of an anhysteritic moment at higher fields. We take the stable direction of magnetization, representing the average geomagnetic field during or shortly after sediment deposition, as the direction at intermediate demagnetization fields. The criterion for recognition of such a direction is that very similar directions are found for at least two successive demagnetization steps. Sample mean directions so identified are given in Table 1, with contributing directions bracketed. Even where a sample exhibits a stable magnetization direction, the possibility remains that mechanical distortion (flowage) of the sediment has taken place during recovery, with a corresponding change in orientation in the stable direction. The parts of the working halves of cores, from which paleomagnetic samples were taken, were carefully checked for visual evidence of flowage. Since most samples were taken from the deeper, more compacted parts of sediment columns, doubt about the undisturbed nature of the material was only occasionally noted. One shallow sample from Site 319 and four deeper samples from Site 320 could not definitely be confirmed as being undisturbed. These samples are indicated in Table 1 and on Figure 1. Sample 319-3-3, $25 \mathrm{~cm}$ consists of very soft material from near the top of the sediment column at this site. Its steep downward inclination is likely to be an artifact. The four Site 320 samples consist of the same compacted material as the other samples at this site and have a similar range of inclinations. The doubt about disturbance here arises from the absence of sedimentary banding in their vicinity, the undisturbed nature of this banding was used elsewhere to confirm the suitability of samples. In the following analysis we exclude the Site 319 sample and retain the Site 320 samples.

Figure 1 shows the distribution of stable magnetization inclinations with depth at each site. The intended concentration of samples in the deeper sediments is evident, as is the lack of trends in inclination with depth. A feature of the inclination distributions is the considerable scatter of values. In part this may be explained by a combination of incompletely averaged nondipole field effects plus the frequent polarity reversals during the time intervals represented by each sampled section (Heirtzler et al., 1968). Proof that field reversal must have occurred between 319-11-6, $22 \mathrm{~cm}$ and 11-6, $125 \mathrm{~cm}$ is in the $160^{\circ}$ difference in the stable magnetization azimuths of these samples, which are referred to the same orientation line.

However, at least one deviation from the anticipated dipole field is apparently of too long a duration to be explained in these ways. This is for the section of core from Hole 320B represented by Samples 320B-2-1, $124 \mathrm{~cm}$ and $2-2,50 \mathrm{~cm}$, both with stable inclinations of $-61^{\circ}$ in contrast with an anticipated value of $\pm 18^{\circ}$. If these steep inclinations are not artifacts, and the field remained steeply inclined throughout this interval, a marked deviation from dipole conditions between $18,000 \mathrm{yr}$ and $27,000 \mathrm{yr}$ is indicated from the range of sedimentation rates (Site Reports, this volume). This is between three and five times the average time for a polarity transition of the geomagnetic field (McElhinny, 1973) and may represent another type of field behavior that has been described as a systematic deviation by Lawley (1970).

In order to estimate plate motion from the paleomagnetic results, it is reasonable to average them with the intention of enhancing the dipole contribution with respect to presumably randomly distributed nondipole field contributions. A major difficulty in averaging low latitude paleomagnetic data, where only inclinations are known absolutely, is that inclination sense is an unreliable guide to polarity. Thus, in low latitude subaerial lava sequences, where both magnetization azimuth and inclination are known absolutely, inclinations of both senses occur for each polarity. This feature is also apparent in the Leg 34 sediments for Samples 319-11-6, $22 \mathrm{~cm}$ and 11-6, $125 \mathrm{~cm}$. Here, cleaned magnetization azimuths differ by close to $160^{\circ}$, indicating that the samples are of opposite polarity, yet both inclinations are downwards. The best possible estimate of dipole field inclination cannot be obtained without a knowledge of the polarity for each sample. However, limits on the range of possible dipole field inclinations can be obtained by making two extreme assumption, i.e., (1) all samples are taken as having the same polarity; and (2) sample polarity is assumed to be indicated by inclination sense.

Figure 2 shows how a single population of vectors of known inclinations would appear when interpreted in each way. The difference in mean inclination, from which paleolatitude is derived, should be noted. 


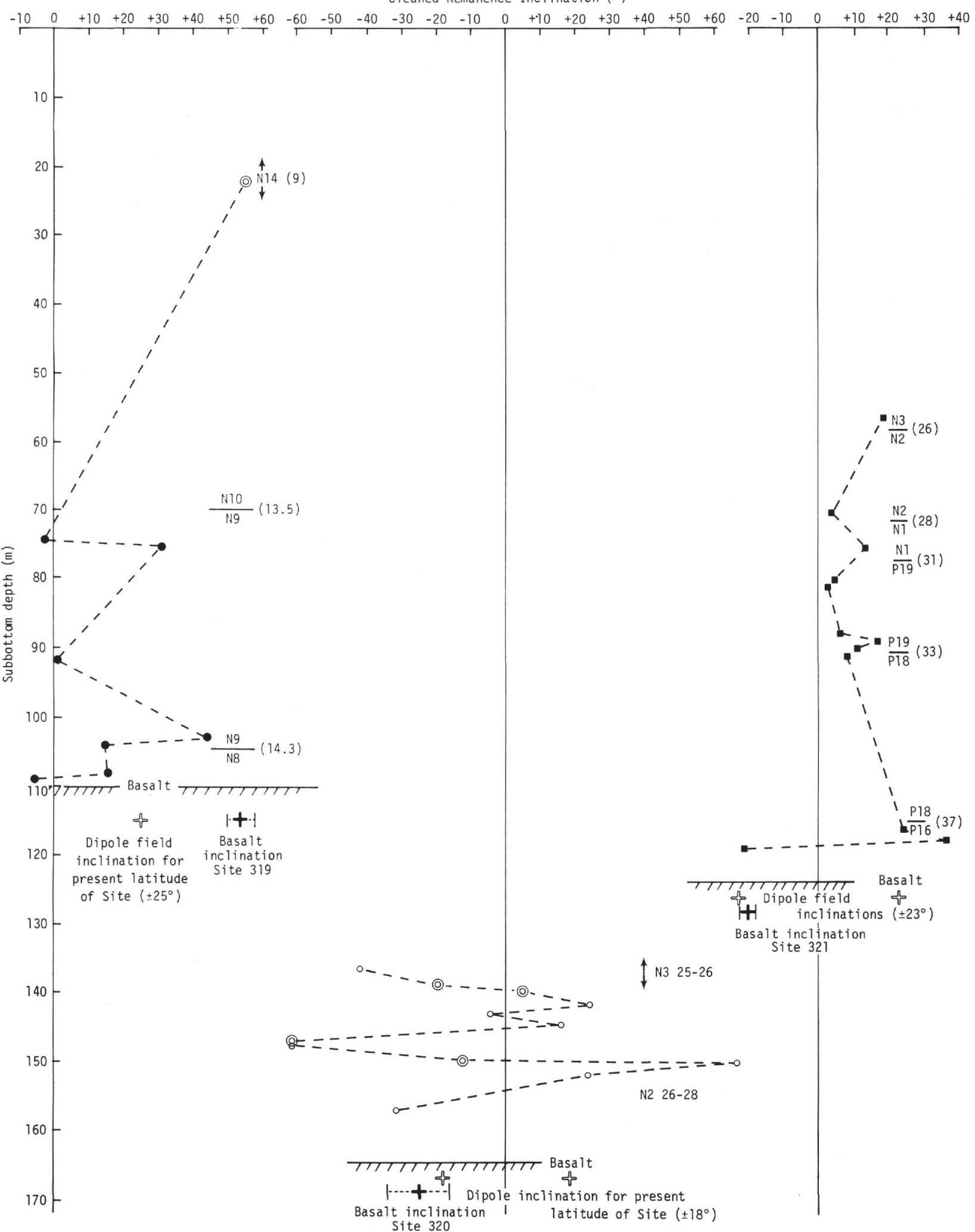

Figure 1. Distribution of sediment stable magnetic inclinations with depth inclinations marked with large rings are for samples that may have been disturbed during recovery. 


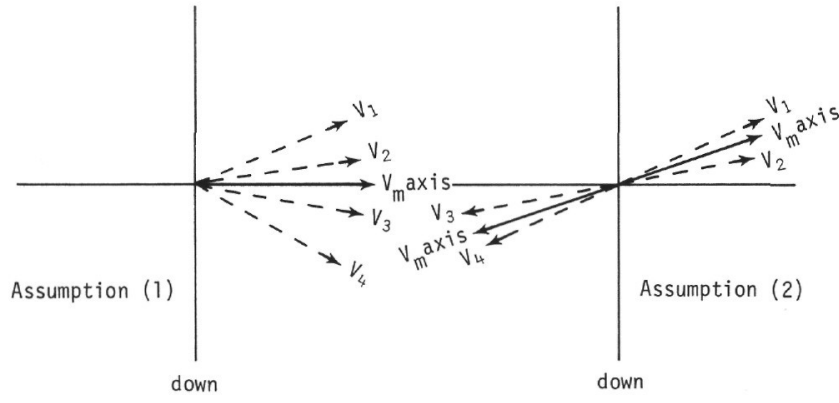

Figure 2. Two limiting assumptions in averaging low latitude paleomagnetic data where only inclinations are known absolutely.

Table 2 lists the stable inclination values for each sample together with mean values calculated on the basis of each assumption. For Sites 319 and 321, the mean values obtained differ only insignificantly while at Site 320 the difference is significant. Table 2 also gives the present site latitudes, and we see that values of the apparent latitude change since magnetization, $\Delta \theta$, given by

$$
\Delta \theta=\theta_{L}-\theta_{P}=\theta_{L}-\tan ^{-1}(1 / 2 \tan I)
$$

where $\theta$ is the present site latitude and $\theta$ the paleosite latitude, are distributed about the $\Delta \theta=0$ line without any obvious trend with sediment age. (Figure 3 ). In constructing this diagram, $\theta_{p}$ values corresponding to
Southern Hemisphere paleolatitudes have been used. Use of the alternative Northern Hemisphere values is reasonably excluded since unacceptably high, southward-directed velocities of about $20 \mathrm{~cm} \mathrm{yr}^{-1}$ would be required over the last 13 m.y. to bring the Nazca plate to its present position. The average of all six $\Delta \theta$ values (two per site) is $+3 \pm 2^{\circ}$ (standard deviation of the mean) which is barely significantly different from zero. We interpret this to mean that the Nazca plate has experienced negligible N-S directed absolute motion over the last 30-40 m.y. The present relatively fast absolute motion of the plate is almost exactly eastwards (Morgan, 1972) which is consistent with the extrapolated sediment paleomagnetism results.

Table 2 and Figures 2 and 3 also show site average inclination and paleolatitude data for the basement basalts. At Sites 320 and 321 the basalt inclinations and paleolatitudes fall within or overlap with the sediment values. This reinforces the case for negligible N-S motion of the Nazca plate over the last 30-40 m.y. The Site 319 basalt data are distinguished by being very far from the Site 319 sediment data, and consequently from the Site 320 and 321 data. The explanation of this result is discussed fully in Ade-Hall and Johnson, Paleomagnetism of Basalts (this volume). The preferred explanation is that the basalts at Site 319 were extruded over a short time interval when the geomagnetic field departed considerably from the centered axial dipole state. In support of this explanation is the recording by the sediments, particularly at Site 320 , of large departures

TABLE 2

Mean Cleaned Paleomagnetic Inclinations for Sediment Samples

\begin{tabular}{cccccc}
\hline Site 319 & $I^{\mathrm{a}}$ & Hole $320 \mathrm{~B}$ & $I^{\mathrm{a}}$ & \multicolumn{1}{c}{ Site 321} & $I^{\mathrm{a}}$ \\
\hline $3-3,25 \mathrm{~cm}$ & +55 & $1-1,6.5 \mathrm{~cm}$ & -42 & $7-6,135 \mathrm{~cm}$ & +19 \\
$8-6,59 \mathrm{~cm}$ & -02 & $1-2,11.5 \mathrm{~cm}$ & -19 & $9-2,119-120 \mathrm{~cm}$ & +04 \\
$8-6,110 \mathrm{~cm}$ & +31 & $1-3,55 \mathrm{~cm}$ & +05 & $9-6,39 \mathrm{~cm}$ & +14 \\
$10-5,31 \mathrm{~cm}$ & +01 & $1-4,101 \mathrm{~cm}$ & +24 & $10-2,110 \mathrm{~cm}$ & +05 \\
$11-6,22 \mathrm{~cm}$ & $+44 \mathrm{~b}$ & $1-5,38 \mathrm{~cm}$ & -04 & $10-3,86 \mathrm{~cm}$ & +03 \\
$11-6,125 \mathrm{~cm}$ & $+15^{\mathrm{b}}$ & $1-6,106 \mathrm{~cm}$ & +16 & $11-1,102 \mathrm{~cm}$ & +07 \\
$12-3,39.5 \mathrm{~cm}$ & +16 & $2-1,124 \mathrm{~cm}$ & -61 & $11-2,55 \mathrm{~cm}$ & +18 \\
$12-3,132.5 \mathrm{~cm}$ & -05 & $2-2,50 \mathrm{~cm}$ & -61 & $11-3,18 \mathrm{~cm}$ & +12 \\
& & $2-3,121.5 \mathrm{~cm}$ & -12 & $11-4,12 \mathrm{~cm}$ & +09 \\
& & $2-4,5 \mathrm{~cm}$ & +67 & $13-1,123 \mathrm{~cm}$ & +25 \\
& & $2-5,42.5$ & +24 & $13-2,99 \mathrm{~cm}$ & +37 \\
& & $2-5,107$ & -31 & $13-3,85 \mathrm{~cm}$ & -21
\end{tabular}

Site Mean Cleaned Inclinations

Assumption 1: All samples taken as having the same polarity (equivalent paleolatitude)

Assumption 2: Sample polarity indicated by sense of inclination (equivalent paleolatitude)

Paleolatitude indicated for underlying basalts

Site latitude

\begin{tabular}{|c|c|c|}
\hline $\begin{array}{l}14 \pm 7^{\circ}(\text { SD of mean }) \\
\left(7 \pm 4^{\circ} \mathrm{N} \text { or } \mathrm{S}\right)^{\mathrm{c}}\end{array}$ & $\begin{array}{l}08 \pm 11^{\circ} \\
\left(4 \pm 6^{\circ} \mathrm{N} \text { or } \mathrm{S}\right)\end{array}$ & $\begin{array}{l}11 \pm 4^{\circ} \\
\left(6 \pm 2^{\circ} \mathrm{N} \text { or } \mathrm{S}\right)\end{array}$ \\
\hline $\begin{array}{l}16 \pm 6^{\circ} \\
\left(8 \pm 3^{\circ} \mathrm{N} \text { or } S\right)^{\mathrm{c}}\end{array}$ & $\begin{array}{l}31 \pm 6^{\circ} \\
\left(17 \pm 4^{\circ} \mathrm{N} \text { or } \mathrm{S}\right)\end{array}$ & $\begin{array}{l}15 \pm 3^{\circ} \\
\left(8 \pm 2^{\circ} \mathrm{N} \text { or } \mathrm{S}\right)\end{array}$ \\
\hline $5 \pm 4^{\circ} \mathrm{N}$ or $\mathrm{S}$ & $13 \pm 5^{\circ} \mathrm{N}$ or $\mathrm{S}$ & $10 \pm 1^{\circ} \mathrm{N}$ or $\mathrm{S}$ \\
\hline $13^{\circ} \mathrm{S}$ & $9^{\circ} \mathrm{S}$ & $12^{\circ} \mathrm{S}$ \\
\hline
\end{tabular}

${ }^{\mathrm{a}}$ Mean cleaned remanent magnetization inclination with respect to the core axis $\left(^{\circ}\right)$

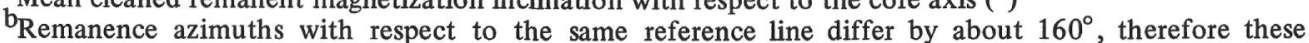
samples have opposite polarity.

'Sample 319-3-3, $25 \mathrm{~cm}$ excluded from the mean values as it is much younger (N14) than the other samples at this site (N8 and N9) and may have been disturbed mechanically. 


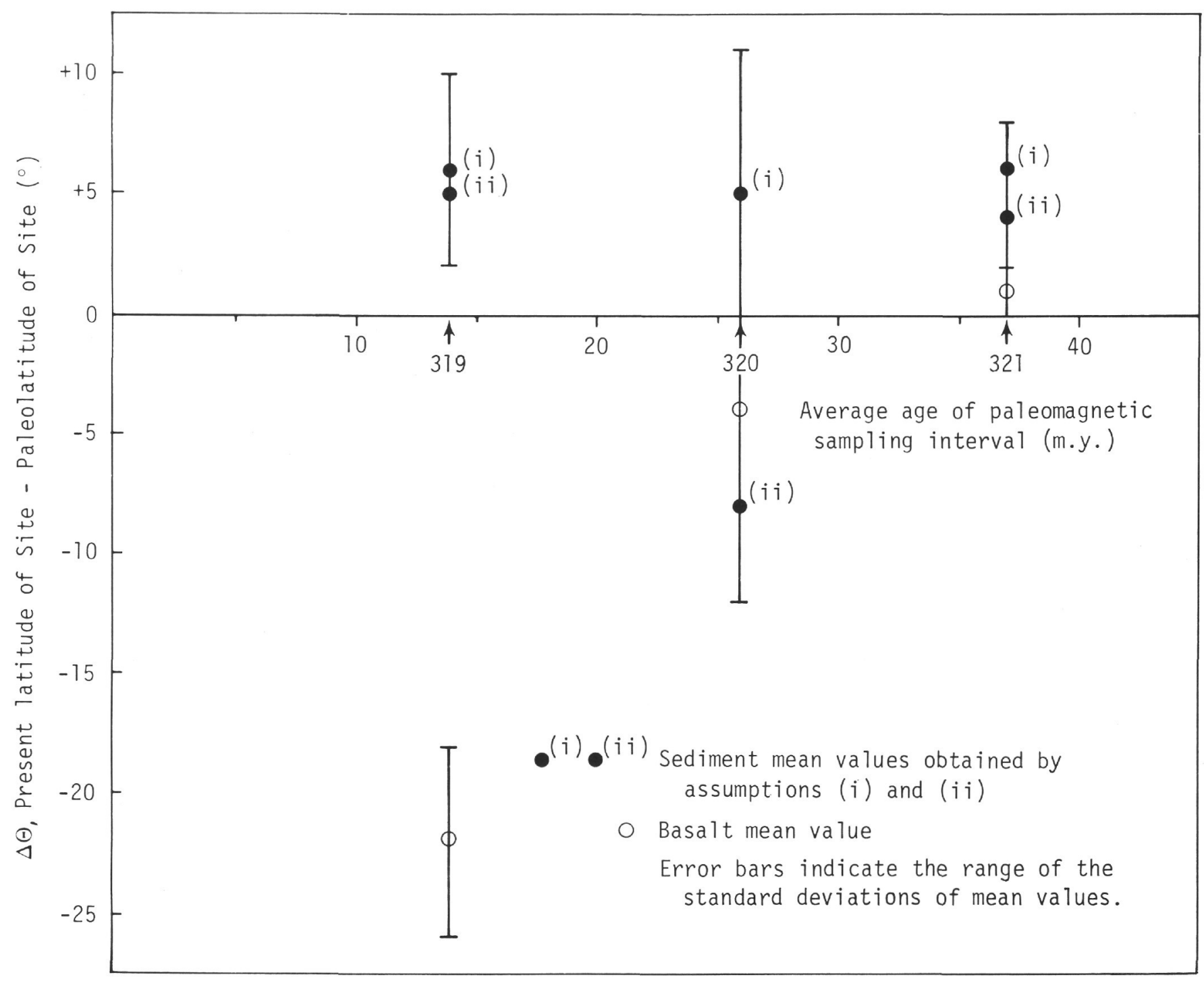

Figure 3. Apparent $N-S$ motion of sites, $\triangle \Theta$ (degrees of latitude) and average age of paleomagnetic sampling material.

from the dipole field state. At this site two adjacent samples have inclinations of $-61^{\circ}$ and a third an inclination of $+67^{\circ}$. If these inclinations are not artifacts and do in fact represent major deviations from the dipole state, it is reasonable to suppose that the site 319 basalts were magnetized during a similar departure from the dipole field.

\section{NRM Intensities and Source of Magnetization of the Sediments}

Sediment paleomagnetic intensities were relatively high at all sites (Table 3 ) although, at three orders of magnitude less intense than the underlying basalts, they contribute negligibly to magnetic anomalies observed at the surface. Most of the paleomagnetism samples were taken from nanno-ooze sedimentary units varying in color from light to dark brown. It was originally thought that the abundant brown material coloring the ooze, apparently a ferruginous phase, was responsible for the relatively strong NRM intensities. However, Mössbauer spectroscopy analyses of a concentrate of
TABLE 3

Mean Sediment Paleomagnetic Intensities with Standard Deviation of the Mean

\begin{tabular}{ccc}
\hline & $\begin{array}{c}\text { Mean } \\
\text { Intensity } \\
\text { Site } \\
\left(\times 10^{-6} \text { emu cm }\right)^{-3}\end{array}$ & $\begin{array}{c}\text { Range of Values } \\
\left(\times 10^{-6} \text { emu cm }\right)^{-3}\end{array}$ \\
\hline 319 & $2.8 \pm 0.4$ & $1.1-4.6$ \\
320 & $1.7 \pm 0.3$ & $0.5-4.4$ \\
321 & $6.4 \pm 1.6$ & $1.9-21.3$ \\
\hline
\end{tabular}

the brown phase indicated that the only detectable ironbearing mineral contains less than $0.1 \%$ of paramagnetic $\mathrm{Fe}^{3+}$ (Jensen, personal communication). The source of the NRM must lie in another phase. Since the smear slides examined showed only the brown material and fragments of nannofossils, and the magnetization of samples was typically distinctly inhomogeneous, we suspect that rare strongly magnetized iron oxide grains are the source of the NRM. Further experimentation is planned to test this hypothesis. 


\section{SUMMARY, CONCLUSIONS, AND RECOMMENDATIONS}

Measurement of the magnetization of at least the more strongly magnetized oceanic sediments onboard Glomar Challenger is quite feasible. Partial demagnetization, needed to isolate the stable, depositional direction of magnetization, requires a better demagnetizing unit than was used on Leg 34. The Schonstedt Instrument Corporation GSD-1 unit, used at Dalhousie University during the continuation of the sediment paleomagnetism project, is quite suitable.

The advantage of shipboard sediment paleomagnetism measurements lies in the more representative dipole magnetic field information carried by a set of sediment samples, as a result of the temporally distinct, time average magnetic information carried by each sample. This representative dipole field information will in general give more reliable estimates of absolute plate motion than will the underlying sequences of basement units, as the latter will often yield too few temporally distinct values of the geomagnetic field.

The Leg 34 sediment paleomagnetism program has yielded two main results: (1) the negligible N-S absolute motion of the Nazca plate over the last 30-40 m.y., and (2) an explanation for the aberrant basalt paleomagnetism results from Site 319 in terms of the recording of a nondipole field feature by a rapidly erupted sequence of flows.
Better quality sediment paleomagnetic data could be obtained relatively easily. The Sperry Sun core orientation device could be used to take completely oriented sediment cores, allowing the polarity of low latitude sediments to be determined. The marking dogs of the orientation device would only have to be arranged in a known orientation with respect to a mark along the length of the core liner.

\section{ACKNOWLEDGMENTS}

We would like to thank John Dewar and Lou Penrod for their generous assistance with the shipboard work and Steven Jensen for a Mössbauer analysis. Patrick Ryall read critically the first draft of this chapter, which was typed by Monika Michaelis.

\section{REFERENCES}

Heirtzler, J.R., Dickson, G.O., Herron, E.M., Pitman, W.C., III, and LePichon, X., 1968. Marine magnetic anomalies, geomagnetic field reversals, and motions at the ocean floor and continents: J. Geoph. Res., v. 73., p. 2119-2136.

Lawley, E.I., 1970. The intensity of the geomagnetic field in Iceland during Neogene polarity transitions and systematic deviations: Earth. Planet. Sci. Lett., v. 10, p. 145-149.

McElhinny, M.W., 1973. Paleomagnetism and plate tectonics: Cambridge (Cambridge University Press), p. 136-137.

Morgan, W.J., 1972. Plate motions and deep mantle convection: Geol. Soc. Am. Mem., v. 132, p. 7-27. 